\title{
¿Aeso lacetana? Nuevos paradigmas en la atribución de territorios a las formaciones prerromanas $^{1}$
}

\section{Lacetanian Aeso? New paradigms in the attribution of territories to pre-Roman formations}

En la bibliografía reciente ha venido prevaleciendo la adscripción de la ciudad romana de Aeso, ubicada en el noroeste catalán, a la formación prerromana de los lacetanos, pese a que en el pasado no faltasen otras atribuciones. Mediante el presente escrito se repasan los argumentos que se emplearon para sostener las adscripciones ilergete, jacetana y lacetana, evidenciando las carencias de los diferentes discursos. Ante el aparente problema de vacío, se propone abandonar el paradigma esencialista en la definición de los étnicos mencionados en las fuentes literarias, señalando la conveniencia de introducir en el discurso la arqueología de la etnicidad aplicada a un grupo protohistórico que habitó un territorio geográficamente definido. Desde esa perspectiva, la urgencia en la atribución a una formación literaria pasa a un segundo plano.

Palabras clave: Aeso, Pirineos, pueblos ibéricos, lacetanos, ilergetes.
Recent research tends to assign the Roman city of Aeso in northwestern Catalonia to a pre-Roman Lacetani settlement despite many other past attributions. This paper reviews the arguments serving to support the Ilergete, Iacetani and Lacetani origins evidencing their different drawbacks. Given the apparent void, this paper proposes an abandonment of the essentialist paradigm in the definition of the ethnic groups cited in literary sources, and points out the convenience of introducing into the discourse of archaeology of ethnicity applied to a Protohistoric group that inhabited a geographically defined territory. From this perspective, the urgency of defining a group from a literary text takes on a secondary role.

Keywords: Aeso, Pyrenees, Iberians, Lacetani, Ilergetes.
1. ID: orcid.org/0000-0003-4509-1703. Este trabajo se enmarca en el proyecto de investigación HAR2014-59503-P: Espacios de integración en la Roma republicana: el N.E. de la Hispania citerior (133-72 a. C.). 


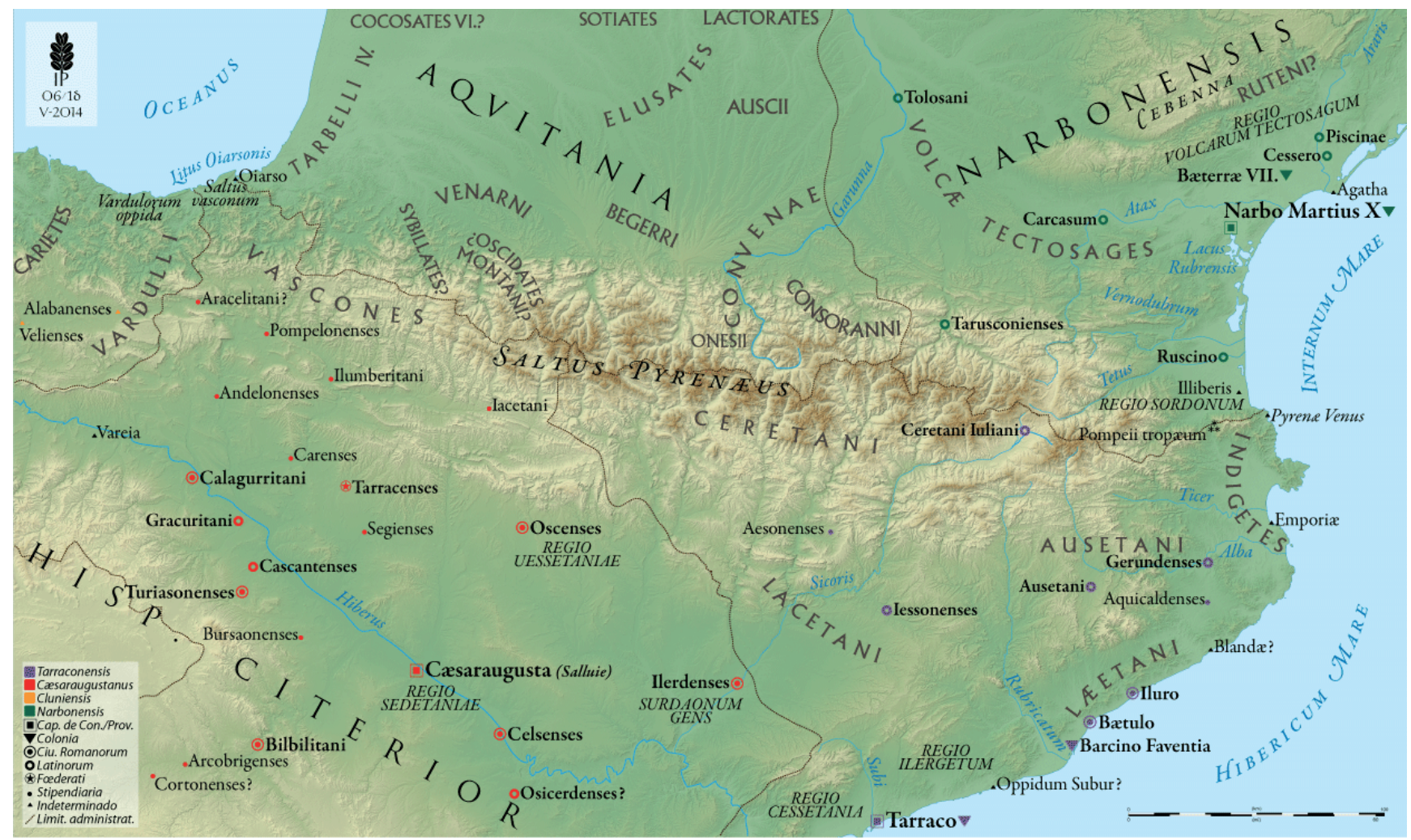

Figura 1. Situación de los principales territorios y comunidades pirenaicas mencionados por Plinio el Viejo (según Imago Pyrenae a partir del material cartográfico de Eric Gaba, Wikimedia Commons user Sting).

\section{Introducción}

El conocimiento arqueológico de la antigua Aeso (Isona, Pallars Jussà, Lleida) pasó del estadio esporádico y erudito a disponer de los primeros datos sistemáticos sobre el trazado urbano, las fases de ocupación y el entorno agrario gracias al meritorio Equipo PRAMA durante los años ochenta-noventa del pasado siglo (Equip PRAMA 1990; Payà et al. 1994a; 1994b). La disolución de dicho grupo frenó ese conocimiento, casualmente continuado mediante la importante intervención que, con carácter de urgencia, fue realizada en el Serrat dels Espinyers entre junio de 2009 y febrero de 2010 (Belmonte 2015: 156-171). Finalizada dicha intervención, se acordó sumar investigadores de ambos momentos y nuevos miembros de la Universidad de Barcelona, que permitiesen reactivar la investigación aportándole la necesaria continuidad institucional. Una de las primeras acciones consistió en la elaboración de un estado de la cuestión desde una perspectiva multidisciplinar, materializada en la redacción de un breve libro editado por la Societat Catalana d'Arqueologia (Garcés, Reyes 2014). En esa obra ya señalábamos las dificultades que subyacen en la atribución, generalmente aceptada, que hace de Aeso el extremo más occidental de la histórica Lacetania (Garcés 2014a: 27-34). Las limitaciones, tanto de espacio como de difusión académica de esa nota, nos han animado a volver sobre el tema, a fin de exponer con mayor detalle los argumentos y conclusiones entonces sucintamente apuntados.
Finalmente, nos ha parecido oportuno realizarlo en el marco del homenaje al profesor Arturo Pérez Almoguera, en reconocimiento a su doble faceta de docente ${ }^{2}$ e investigador aesonensis. ${ }^{3}$ En la realización de este trabajo hemos contado con valiosas sugerencias de diversos estudiosos, a los que agradecemos sus comentarios, ${ }^{4}$ aunque los errores que finalmente pueda contener son responsabilidad del autor.

\section{Situación}

La ciudad romana de Aeso se ubica en el Prepirineo catalán (figura 1), a $663 \mathrm{~m}$ de altura. En parte se encuentra bajo el casco urbano de la actual villa de Isona, que deriva su nombre del topónimo antiguo, y en parte bajo los huertos, hasta no hace mucho activos, que se extienden al sur de dicho núcleo (Garcés, Reyes 2014). El emplazamiento aprovecha el extremo de una terraza natural que finaliza de forma más pronunciada hacia el oeste, entre los arroyos de Mas de Mitjà y la Colomera, cuando ambos confluyen en el barranco de Solans, tributario del riachuelo Conques, afluente por la izquierda del río

2. En reconocimiento a su magisterio durante nuestros años formativos en el Estudi General de Lleida, hoy Universidad de Lleida.

3. Recordemos sus contribuciones a la prosopografía y epigrafía de Isona: Pérez 1994; 1998; 1999 y 2002.

4. Agradezco las lecturas críticas realizadas por el Dr. Joaquín Ruiz de Arbulo (Universidad Rovira i Virgili) y por el Sr. Víctor Sabaté Vidal (Universidad de Barcelona). 
Noguera Pallaresa y vertebrador de una subcomarca natural, la Conca Dellà. Ese espacio es, a su vez, una porción de la comarca administrativa del Pallars Jussà y, por extensión, de la comarca histórica del Pallars. La Conca Dellà, rodeada de sierras calcáreas que oscilan entre los 1.000 y los 2.000 metros, goza de una climatología muy diferente de las cercanas zonas de alta montaña del Pallars Sobirà, puesto que se ve afectada por un clima mediterráneo continental favorecedor de los cultivos.

\section{Una sola mención literaria segura}

La única fuente antigua que menciona Aeso de manera inequívoca es Plinio el Viejo $(N H 3,4,23)$. El pasaje pliniano dice:

Nunc per singulos conuentus reddentur insignia praeter supra dicta. Tarracone disceptant populi XLII, quorum celeberrimi ciuiun Romanorum Dertosani, Bisgargitani; Latinorum Ausetani, Ceretani qui Iuliani cognominantur et qui Augustani, Edetani, Gerundenses, Gessonienses, Teari qui Iulienses; stipendiariorum Aquicaldenses, Aessonenses, Baeculonenses. ${ }^{5}$

El texto trata de la adscripción conventual a Tarraco de diversas comunidades y la exposición no sigue un orden geográfico o étnico, se estructura según una prelación jurídica. Así, en primer lugar se mencionan las comunidades que gozan del derecho romano, a continuación las que poseen el latino y, en último lugar, las que todavía eran estipendiarias al final de los Julio-Claudios, momento en que se generan los informes que utiliza el naturalista romano. ${ }^{6} \mathrm{El}$ pasaje en cuestión no afirma que los Aessonenses = Aesonenses hubiesen tenido un origen lacetano, ni, por supuesto, tampoco en otras etnias, pues es evidente la finalidad del escrito. Aún así, se suele señalar, y es lógico aceptar, que si los ilerdenses, antiguos ilergetes, estaban adscritos al conuentus de Caesaraugusta, como se indica algo más adelante en la misma obra (NH 3, 4, 24), y los aesonenses no, estos últimos no eran ilergetes. El razonamiento es válido, pero al proseguir en la búsqueda de una etnia citada por las fuentes que supla la inconcreción se acude a la ciudad vecina más cercana, que resulta ser, hacia el sureste, Iesso (Guissona, la Segarra). Y, dado que esta aparece mencionada por otro autor, Ptolomeo (Geog. 2, 6, 71), como inequívocamente lacetana, ${ }^{7}$ ¿qué otra cosa puede ser sino Aeso? Ello conduce a un razonamiento inductivo, donde las premisas son verdaderas pero no se tiene la seguridad que la conclusión final lo sea.

5. FHA VII, 123: "Ahora, convento por convento, se indicarán las cosas notables además de las anteriormente mencionadas. De Tárraco dependen 42 pueblos, de los cuales los más famosos son: de ciudadanos romanos, los dertosanos y los bisgargitanos; de latinos, los ausetanos, los ceretanos, a los que se da el sobrenombre de «Julianos» y también de «Augustanos», los edetanos, los gerundenses, los jesonienses y los tearos o «julienses»; de estipendiarios, los acuicaldenses, los aesonenses y los baeculonenses".

6. Sobre comparaciones del método de trabajo del autor con Estrabón, ver: Cruz-Andreotti 2017; con Ptolomeo, ver: Beltrán Lloris 2012.

7. El texto dice iaccetani, pero puede ser corregido en lacetani por el contexto.
Cierta bibliografía ha querido incluir dos referencias literarias más sobre Aeso, pero ambas son descartables. La primera es referente a una variante contenida en el aludido pasaje de Ptolomeo (Geog. $2,6,71)$ sobre el que volveremos más adelante. La segunda no merece mayor comentario, pues es la equívoca presencia de un obispo de Aeso en el VI Concilio de Toledo (FHA IX: 294; Pita 1967: 2; Tovar 1989: 451; Bertran 2007: 50); en realidad, se trata de una corrupción textual y debe rectificarse la lectura Aeso por Auso (Rodríguez 1992: 335, n. 426; Garcés 2014b: 126).

\section{Las diferentes tradiciones de adscripción}

\section{La adscripción ilergete}

La extensión septentrional de los confines ilergetes, formación ibérica centrada en los llanos que recorren los cursos bajos de los ríos Segre y Cinca, fue ampliada hasta el Pirineo, de forma ciertamente generosa, por una antigua tradición erudita que se remonta al siglo XVII. En ella no se menciona el caso específico de Aeso, pronto identificada de forma segura en Isona gracias a las tempranas lecturas epigráficas que hacían constar la condición de aesonense de algunos de sus habitantes; en realidad se infería por medio de la inclusión general que se daba a los límites de las etnias prerromanas.

Uno de los primeros defensores de la extensión de los ilergetes hasta los Pirineos fue Pierre de Marca (1594-1662) en su obra póstuma Marca Hispanica (1688). Deudor de los geógrafos antiguos, el autor bearnés sitúa los ilergetes entre los Pirineos, a Oriente, y el río Ebro, a Occidente, teniendo los vascones al norte y los lacetanos y cesetanos al sur (Olives 1840: 145). También Pedro Juan Finestres (1690/91-1769), profesor de derecho canónico en la Universidad de Cervera y canónico de Lleida, los extiende por el norte hasta las raíces del Pirineo, algo sobre lo que más tarde se mostró escéptico el historiador leridano Marià Olives (1787-1845), acudiendo para ello a la autoridad de Estrabón (Olives 1840: 145).

Un paso importante en la concreción de Aesona como "famosa ciudad de los ilergetes" lo dio el político e historiador liberal Javier Martínez Marina, confinado en Lleida en 1818-1820, donde redactó su inédita Descripción geográfica de los pueblos ilergetes, que José de La Canal transcribió en el volumen XLVI de la España Sagrada (La Canal 1836: 15). Por esas fechas la polémica se centró más en la correcta ubicación de Aesona que en su adscripción. Todavía, contra la correcta ubicación de Aeso, Miguel Cortés y López (1777-1854), en su Diccionario geográfico histórico de la España Antigua, publicado en 1833, intentó situar dicha ciudad en Manresa (Lara 1973: 177), pero fue refutado poco después, en 1839, por el jurista de origen pallarés Ramon Roig i Rey (1793-1861), devolviendo, con propiedad, la ubicación a Isona (Roig i Rey 1868: 239).

Como se ha visto, la tesis ilergete carecía de apoyo en las fuentes literarias y a la altura de inicios del siglo xx fue desplazada por la tesis lacetana, que más adelante analizaremos. Tardíamente, solo fue continuada por algún trabajo de juventud de Rodri- 
go Pita (1952: 297), contestado mucho después por Christian Rico (1997: 168, nota 39), aunque el autor francés omita que en la producción de madurez de Pita este ya se había autocorregido y la atribuía a los lacetanos (Pita 1967: 7-8; 1975: 44-45).

En los foros académicos se ha demostrado el enorme problema que arrastró la investigación hispana durante décadas al poner en el mismo nivel las fuentes arqueológicas y las literarias, buscando obtener respuestas análogas, como si la naturaleza de la información que suministran fuese comparable (Cruz-Andreotti 2009: 64). Ese no fue, sin embargo, el caso que nos ocupa. La cultura material no participó en la construcción del discurso de ubicación de Isona, pues hasta la excavación del Tossal de les Tenalles de Sidamon, en 1915, no comenzó, lentamente, a ser definido desde un punto de vista material qué era ilergete. Y en el Pallars todavía no ha hecho sino que comenzar ese conocimiento. Aquello que durante décadas se conoció como la cultura material protohistórica del Jussà y del Montsec se limitaba a los datos derivados de las exploraciones de las cuevas, lugares que muestran abundante actividad justo antes de la época que nos interesa, en la que son drásticamente abandonadas. No obstante, el límite septentrional de la ya identificada cultura material ilergeta servía, indirectamente, para fijar el extremo de su influencia en las crestas de la sierra del Montsec. Desde el último cuarto del siglo xx la mayoría de estudiosos señalaron ese accidente como el límite septentrional ilergete (Pita 1975: 45; González Pérez 1986: 278-279; Garcés 1991: 23-25), al tiempo que la definición arqueológica del llamado Grupo Segre-Cinca (Junyent 2003), que arrancaría en la Edad del Bronce y finalizaría en tiempos ilergetes, definía con claridad el proceso formativo de los ilergetes en el llano.

Por el contrario, el panorama arqueológico ibérico e iberorromano en las zonas abiertas del Pallars Jussà solo ha salido en parte a la luz a comienzos del siglo xxi, y aunque lo explorado todavía sea inicial, cuando menos se dispone ya de tres campos de silos: Llirians del Mas-Las Torres (Salàs de Pallars) (Piera et al. 2013), Serrat dels Espinyers (Isona) ${ }^{8}$ y el inédito Planell de Santamaria (La Pobla de Segur). Precisamente, en base al último yacimiento se ha vuelto a señalar una posible expansión ilergete por la derecha de la Noguera Pallaresa más arriba del Montsec (Cots 2005: 37), que no afectaría a Isona; aún así la consideramos una afirmación precipitada. De igual forma, algún historiador local ha vuelto a incluir el Pallars en el poblamiento ilergete sin más argumentos (Bertran 2007: 27).

Aunque modestas en número, las cerámicas a torno oxidadas de Llirians del Mas-Las Torres, en la derecha de la Noguera Pallaresa, sugieren artesanos locales que se mueven en un medio iberizado cuando menos a inicios del siglo IV a. C. Los aspectos formales admiten influencias desde la activa zona ilergete, pero no exclusivas, como indica la presencia de algunas

8. Resumen del yacimiento en Belmonte 2015; sobre la cultura material: Garcés, Cama 2014: 61-78; la sociedad ibérica: Belmonte et al. 2015; indicios de un posible campamento romano republicano: Padrós et al. 2016. cerámicas grises, incluso estampilladas, que hablan de contactos simultáneos con la Cataluña central. En el margen izquierdo del río, en El Serrat dels Espinyers, se ha localizado el, hasta el momento, más septentrional hallazgo seguro de un fragmento de cerámica de barniz rojo ilergete (Garcés, Cama 2014: 74), explicable como un intercambio comercial. Una relación continuada en el tiempo, pues la analítica confirma para la época iberoromana la importación de otro fragmento, esta vez pintado, con pasta análoga a las series ibéricas recuperadas en la ciudad de Ilerda (Buxeda, Madrid 2014: 95-96). Si dejamos al margen las siempre personales apreciaciones de influencias formales y pictóricas, que también creemos se dieron de sur a norte, admitiremos que estamos delante de dos zonas relacionadas pero diferentes.

\section{La adscripción jacetana}

Durante el segundo tercio del siglo XIX se estableció una curiosa asociación entre Isona y el nombre de una ciudad recogida por el geógrafo del siglo II Claudio Ptolomeo (Geog. 2, 6, 71) situada entre los iacetani (Cortés y López 1836; Madoz 1845: 20). Estos autores utilizaban una de las variantes de los códices conservados del alejandrino, la que dice Lisa o Isa, para la que sugerían un tan romántico como improbable origen griego (recordemos la griega Issa, actual Vis, en la costa dálmata). No veían ningún inconveniente en establecer una particular evolución fonética con el cambio de la $-a$ final en $-O$, para deducir que durante la Edad Media recibiría el añadido de la sílaba final -na, convirtiendo así la "griega" Isa en la moderna Isona. La singular asociación incluso obviaba el bien conocido nombre romano de Aeso, y establecía una pretendida vinculación pirenaicojacetana mediante Ptolomeo.

Un paso importante se produjo a finales del siglo XIX cuando Karl Müller analizó y fijó las tablas ptolemaicas (Müller 1883-1901: 195b). Dicho autor concluía que el nombre de la ciudad jacetana era $\Lambda \eta j \sigma \alpha$ $(L \bar{e} s a)$, lectura seguida entre nosotros por Antonio Tovar (1989: 451). Lisa quedaba así invalidada. Pero Müller, en una nota al pie estableció una nueva asociación que iba a tener largo recorrido y que consistía

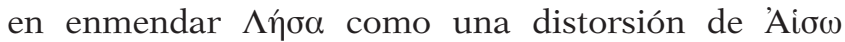
(Aiso $).{ }^{9}$ La corrección, con dos vocales iniciales y tema final en -o, podía, así, relacionarse con los aesonenses mencionados por Plinio. En esta construcción, los aesonenses eran adscritos al pueblo pirenaico de los jacetanos, el mencionado por Ptolomeo.

Medio siglo más tarde, la perspicacia de Julio Caro Baroja (1952: 710 y 732) relacionó la leyenda monetal eśo con la cita ptolemaica, que él identificaba como 'Aiøw al seguir el prestigio de Müller, pero añadiendo que debería corregirse la atribución de los jacetanos a la de los lacetanos, al reconocer que ambos pueblos no se citaban nunca juntos en las fuentes antiguas. Es posible que en esta propuesta influyese también la

9 Para Müller: $\Lambda \eta ́ \sigma \alpha=$ AEso. En otros códices: $\Lambda \hat{\sigma} \sigma \alpha$ o

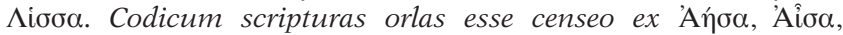
quod ipsum depravatum ex 'Aĭow. 

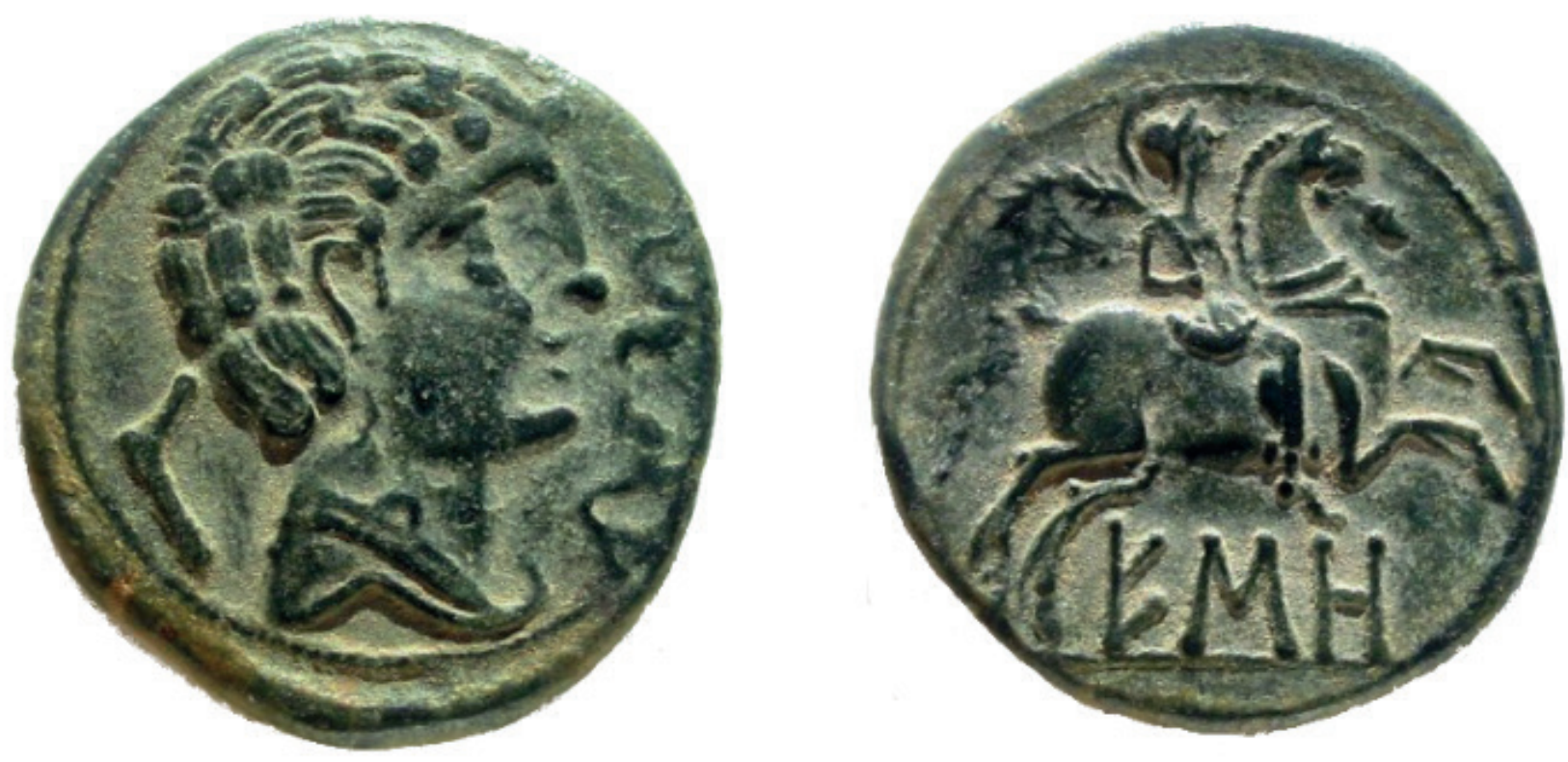

Figura 2. Moneda de bronce de la ceca de eśo (foto: Eric Gaba).

posibilidad de conciliar Ptolomeo con la adscripción lacetana, ya consolidada por esas fechas.

Sin embargo, la identificación de esa ceca con la ciudad recogida por Ptolomeo descansa sobre dos correcciones consecutivas, un aspecto poco probable (Collantes 1997: 158-159). Además, la primera corrección debe ser descartada: todas las ediciones críticas modernas de Ptolomeo rechazan la lectura propuesta por insegura y la consideran una simple variante accidental (Siles 1985: n. 958). El nombre

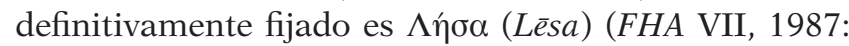
95, 198; García Alonso 2003: 413). 'A ya aparecía relegada a la condición de variante en la edición de Müller ( $c f$. TIR J/K-31: 32), García Alonso ni tan solo la incluye en su moderna revisión, pero sí indica la variante $\Lambda \iota \sigma \sigma \alpha$ (Lissa). En conclusión, Ptolomeo hablaría de una ciudad jacetana, hoy todavía no localizada, que no sería Aeso sino Lesa. La tesis jacetana, ya descartada por Caro Baroja, pierde definitivamente cualquier atisbo de veracidad con el establecimiento de la lectura correcta del topónimo ptolemaico.

\section{La ceca de éso}

Fijado el texto de Ptolomeo, y descartada su inclusión entre las fuentes que mencionan Aeso, debemos pasar a analizar otra relación: la establecida entre la eśo monetal (figura 2) y los aesonenses de la epigrafía y, por consiguiente, con Isona. La atribución de esa ceca a la ciudad romana quedó establecida por Pío Beltrán en su ordenación de las cecas pirenaicas (Beltrán 1953: 28). Pese a las similitudes fonológicas no se disiparon las dudas de tal ubicación, básicamente por dos aspectos. El primer escollo lo constituía la alerta dada por los estudiosos de la numismática sobre los pocos hallazgos de monedas de eśo localizados en Isona, limitándose la mayoría de recuperaciones conocidas a ciudades como Azaila y otros puntos indeterminados de Aragón (Martín Valls 1967: 46), por lo que se sugería desplazar la ceca más al oeste, posición que ha sido seguida hasta la actualidad por algunos autores (García-Bellido, Blázquez 2002: 143144; Chaves 2009: 73). El segundo es de naturaleza filológica. En 1975 J. Untermann, después de someter el nombre de la ceca a las leyes evolutivas que caracterizan el paso de los topónimos ibéricos a los romanos, dudaba de la tradicional asociación entre ceca ibérica y ciudad romana (MLH I: 201, A.17).

Consideramos que el primer argumento, la distribución de los hallazgos, no es concluyente, puesto que la expansión del numerario conocido por la zona central del Valle del Ebro evidencia la región económica en la que se integra la ciudad, no su ubicación. En relación con esa duda habría sido de utilidad conocer la composición de las monedas localizadas de antiguo en Isona, donde había ejemplares de esa ceca, y que pasaron a formar parte de la colección que el religioso, y primer explorador de Isona, Jaume Pasqual reunió en el monasterio de Santa Maria de Bellpuig de les Avellanes (Velasco 2011: 61). A falta de ese dato, hoy irresoluble, puede acudirse a Villaronga ( $\mathrm{CNH}$ : 183), quien recoge noticias inconcretas de nuevos hallazgos de monedas de eśo en la zona de Isona. También resulta sugerente la nueva información obtenida en la intervención del Serrat dels Espinyers: entre el reducido conjunto de monedas recuperadas e inéditas, que no pasan de 40, se documentan dos de eśo (Arcos, Belmonte 2011: 182), y ello pese a ser una ceca modesta.

Las objeciones filológicas pueden explicarse como un caso de ultracorrección (Mariner 1972: 295; Faria 2007: 180; 2008: 66), en el que la adaptación eśo > Aeso debería tener lugar en un momento en el que 
en el latín ya se ha producido la monoptongación de [ae] en [ع], datada en el siglo I a. C., que establecería la siguiente secuencia irregularmente latinizada: ib. [eso] > lat. [eso] <aeso>. Por otro lado, J. Coromines ya incluyó el topónimo entre los nombres prerromanos de tipo ibérico en -on, que los romanos adaptaron en $-\mathrm{o}$, ib. [aison] > lat. [aeso(n)] (On. Cat. IV: 450 b51 y ss.).

Con independencia de la ubicación concreta de la ceca surgió una duda sobre su iberismo cuando diversos autores quisieron ver en eśo un topónimo de origen indoeuropeo (Villar 2000: 303; 2001: 263, 267; Rodríguez Morales 2001: 114 y 121, n. 39; Villar et al. 2012: 268-275 y 608-609; Jordán 2012-2014 179 y 182), aspecto que no es determinante para el tema principal que nos ocupa, puesto que esos mismos autores también habían querido ver en los Lacetani esos mismos orígenes (Villar 2001: 267). En esa línea, García Alonso (2003: 413-414) ha realizado un esfuerzo para incluir la forma latina Aeso entre los topónimos de origen céltico, señalando los parecidos con Aisa (Duratón, Segovia), Aisus (Hinojosa de Duero, Salamanca), Haesus (Lara de los Infantes, Burgos) y la Eso de Salvatierra (Trujillo, Cáceres), e, incluso, con teónimos contenidos en los antropónimos britanos Aes-ica y Es-ica. Debe decirse que todo ello ha sido realizado sin tener nunca en cuenta la forma ibérica del NL.

Hace más de veinte años que António Marques de Faria ha venido defendiendo eśo como un topónimo ibérico con sufijo en -o, mostrándose crítico con la adscripción indoeuropea ${ }^{10}$ (Faria 1995: 326; 2002: 129; 2007: 180; 2008: 66; 2016: 160); posición compartida con Untermann (MLH I.1, 180) y con Javier Velaza al repasar de nuevo el elemento -o en la formación de topónimos en el área lingüística ibérica (Velaza 2011). Topónimos sin sufijos y con final en $-\mathrm{o}$ se pueden hallar en otras cecas ibéricas catalanas, como laứ-o (CNH 195; 1-17), ieś-o (CNH 199; 1-4) o iltứ-o (CNH 193; 1-16).

En síntesis, eśo es la leyenda de una ceca ibérica relacionada con Aeso-Isona (MLH I, A.17; CNH 1994: 183-184), así lo aceptan numismáticos e historiadores (Guadán 1980: 95; Ripollès 1996: 312-313; Pérez 1996: 51-52; 2003: 205; Domínguez 1997: 138; Collantes 1997: 158-159; Campo 2005: 78; Amela 2015: 31-34). La ceca fue modesta, solo acuñó unidades de bronce y seguramente lo hizo durante un período de tiempo no muy largo, que Collantes (1997: 159) sitúa a finales del siglo II a. C. y, con mejor criterio, Villaronga (CNH: 183) rebaja al primer tercio del siglo i a. C. El hallazgo de un ejemplar en el tesoro de Azaila I, muy poco desgastado, induce a Marta Campo (2005: 78) a fechar el taller en los años 90-80/70 a. C. La iconografía depende estrechamente de los modelos de iltiŕta (en último lugar: Amela 2015: 32). La ciudad no es ilergete, pero las emisiones muestran, una vez más, un estrecho contacto con esa formación, en sintonía con la cultura material.

10. En nuestra primera exposición (Garcés 2014a: 32) incluimos por errata a A. M. Faria entre los seguidores de la posición indoeuropea, como el mismo autor ya ha señalado (Faria 2016: 160).

\section{La adscripción lacetana}

Otra tradición que, como mínimo, surge a inicios del siglo xx, sitúa Aeso entre la etnia de los lacetanos, formación que se habría extendido por los altiplanos de la Cataluña central antes de la llegada de los romanos. Las bases sobre las que descansa son el mencionado texto pliniano de no acudir a Caesaragusta, como los ilerdenses, y, en ocasiones, el pasaje de Ptolomeo, donde se cree leer Aeso, corregida de jacetana a lacetana.

El espacio pirenaico, que otrora se atribuyó a los ilergetes, ya ha mudado en el geógrafo Francesc Carreras Candi (1908: 816 y mapa s/n), quien realiza una confusa ubicación de los lacetanos sin distinguirlos del todo de unos jacetanos cercanos al Pirineo. Significativamente, la propuesta lacetana irá ganando carta de naturaleza entre los historiadores catalanes del momento. Sin mayores explicaciones, Antoni Rovira i Virgili (1922: 518) les atribuye las localidades de Manresa, Guissona, Isona y Solsona, lo que equivale a sustentar que ocuparon el centro de Cataluña en sentido amplio. Será el prehistoriador Pere Bosch Gimpera quien dará algunas razones sobre esta inclusión (Bosch 1932: 365-366):

...Aeso, que es suposa Isona. En aquest cas els lacetans arribarien fins a l'alta província de Lleida, més enllà del Montsec; però, essent el principal nucli de llurs ciutats més ençà de l'angle muntanyós que limita la conca de Tremp (Montsec, serres de Comiols), Isona resta molt separada de la major part del territori lacetà i fa l'efecte d'una avançada de caràcter estratègic establerta a l'angle sud-est de la conca de Tremp, que domina des de la seva situació elevada tot just en començar el vessant de les serres de Comiols pels passos de les quals estaria unida amb el territori del Segre mitjà i per ell a la resta del territori lacetà.

El carácter de "avanzada" hacia el oeste parece ser premonitorio respecto del trágico papel que la villa de Isona desempeñará poco después en el bando republicano durante la Guerra Civil. Sin embargo, es obvio que ese rol no puede extrapolarse a tiempos prerromanos. Bosch Gimpera y Adolf Schulten extendieron los lacetanos hasta el Pirineo oriental (Broch 2004: 13). Aunque en sentido estricto el hispanista alemán no se pronunció sobre Isona, sí consolidó el papel de los lacetanos como etnia, además de resaltar sus deterioradas relaciones con la etnia más occidental de los suessetanos, según se desprende de la utilización de un contingente auxiliar de los segundos por parte de Catón, para hacer caer una ciudad de los primeros en una trampa (Liv. 34, 20), lo que, de paso, obligaba a justificar cierta vecindad. El enorme prestigio y larga influencia que ejercieron Schulten y Bosch entre los historiadores y arqueólogos posteriores, consolidó esas atribuciones.

Pero hay más elementos en el debate. La imagen de Bosch, que hacía de Aeso una especie de bastión avanzado lacetano, implicaba fragmentar una comarca como el Jussà, desgajando el extremo suroriental y dejando el resto en otras manos para contentar una determinada lectura de las fuentes. De rebote, obligaba a justificar que el Segre Medio, o al menos una parte del mismo, estaba en poder de los lacetanos, 


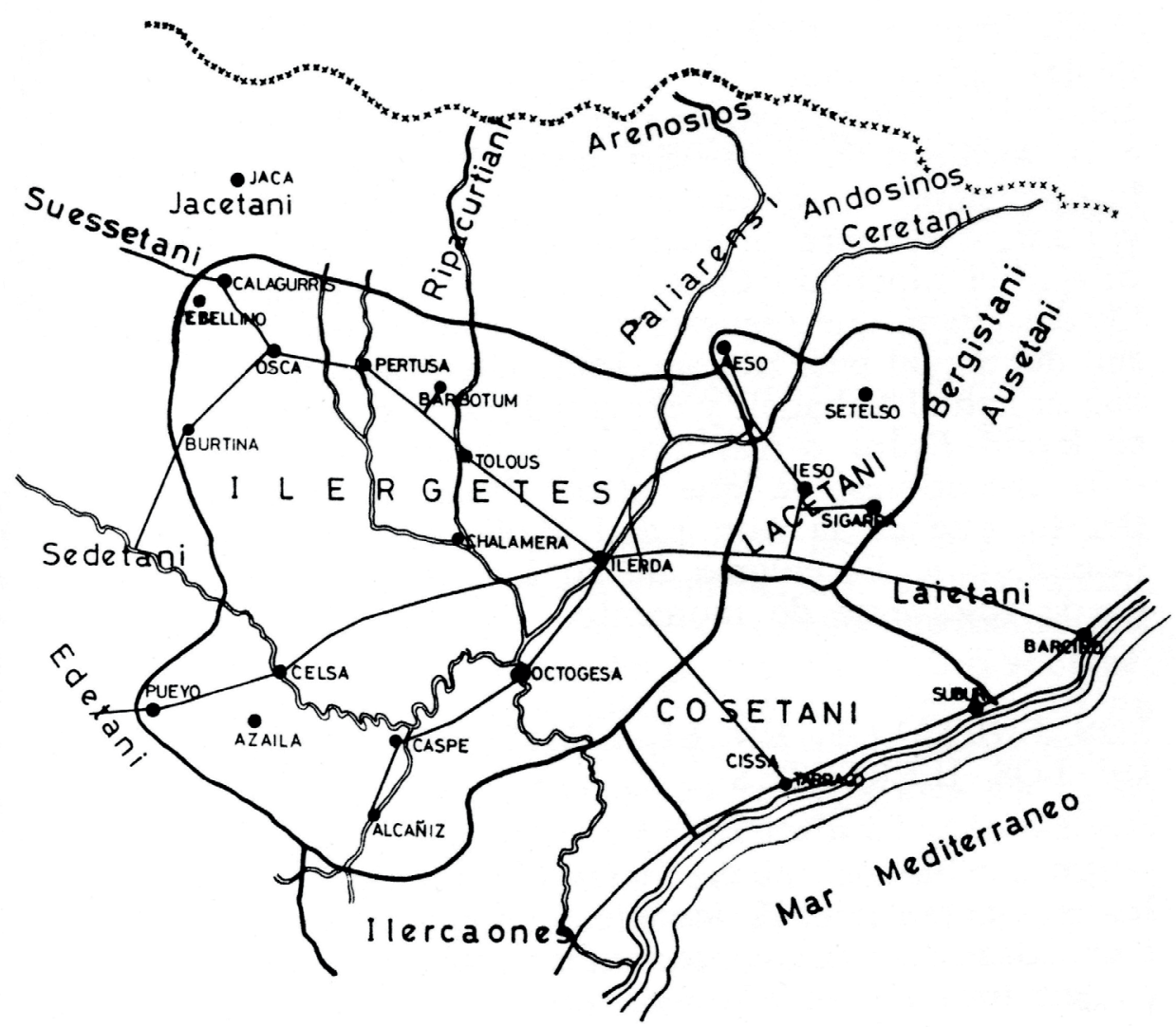

Figura 3. Ilergetes y lacetanos según la reconstrucción de R. Pita (1975: 45).

algo que nosotros mismos aceptamos en el pasado (Garcés 2005). La formulación de Bosch daba a entender que predominaba la formación política sobre la étnica, pues nos venía a decir que nada sabíamos del origen local pero poco importaba, pues acaba absorbida por los lacetanos, en su expansión desde la costa al tiempo que estos se diferenciaban definitivamente de los layetanos (sobre lo segundo, ver: Broch 2004: 13-14).

La lacetanidad de Aeso ha sido la tónica dominante tanto en el panorama de los estudiosos profesionales, ya fuesen historiadores o arqueólogos (Pons 1982: 21; Equip PRAMA 1990: 111; TIR: 32; Pérez 1999: 362; Beltrán Lloris 2001: 70, 73 y mapa 2; Pina Polo, Alfayé 2002: 203 y 211), como entre los estudiosos locales (Pita 1963: 219; 1967: 2; 1975: 44; Sanfeliu 1977: 8-9; Bertran 2007: 27). Y cuando se ha optado por reflejar esa imagen en los mapas que acompañaban las reconstrucciones de los pueblos antiguos, se ha plasmado gráficamente el diseño formulado por Bosch (figura 3), sin reparar en que se producía la fragmentación de un espacio geográfico, ni en las dificultades de prolongar en el tiempo un enclave a través de pasos de montaña (Pita 1975: 45; Sanfeliu 2009: 44-47).

Una variante de la posición anterior, al menos más coherente con la geografía, pasa por entregar a los lacetanos el conjunto del Pallars (Sánchez i Vilanova 1996: 8; Rico 1997: 167, fig. 3, 168), lo que suaviza el concepto de enclave formulado por Bosch. Christian Rico (1997: 168-169) incluso introduce una nueva razón, ahora de carácter comercial:

Les raisons de ce déplacement de frontières restent assez obscures. Une explication possible pourrait être que les Lacetani avaient cherché à contrôler une vallée pyrénéenne qui leur offrait une liaison avec la Gaule. Dans cette hypothèse, ce ne pouvait être la haute vallée du Llobregat barrée en amont par la muraille du Cadí, ni la haute vallée du Sègre qui dépendait alors des Cerretani. Il n'y a donc aucune raison pour limiter l'expansion territoriale dels Lacetani à la seule région de Tremp (c'est la solution que retient en effet N. Dupré, Frontières, carte 2); elle engloba très sûrement la haute vallée de la Noguera Pallaresa —région actuelle du Pallars Sobirà- qui leur offrait ainsi, par le port de la Bonaigua, une sortie sur la province d'Aquitaine.

Podemos aceptar de Rico la sugerente idea que en época imperial romana Aeso se proyectaba a través de todo el Pallars en dirección a Aquitania, en el futuro la arqueología se encargará de confirmarlo o desmentirlo. No obstante, parece excesivo retrotraer esa posibilidad hasta tiempos prerromanos. En la reconstrucción de Rico, todas las formaciones indígenas pugnan entre sí por disponer de una salida pirenaica (figura 4), si Aeso es para los lacetanos, Labitolosa, como compensación, es para los ilergetes (Rico 1997: 175), y eso que considera, además, ambas 


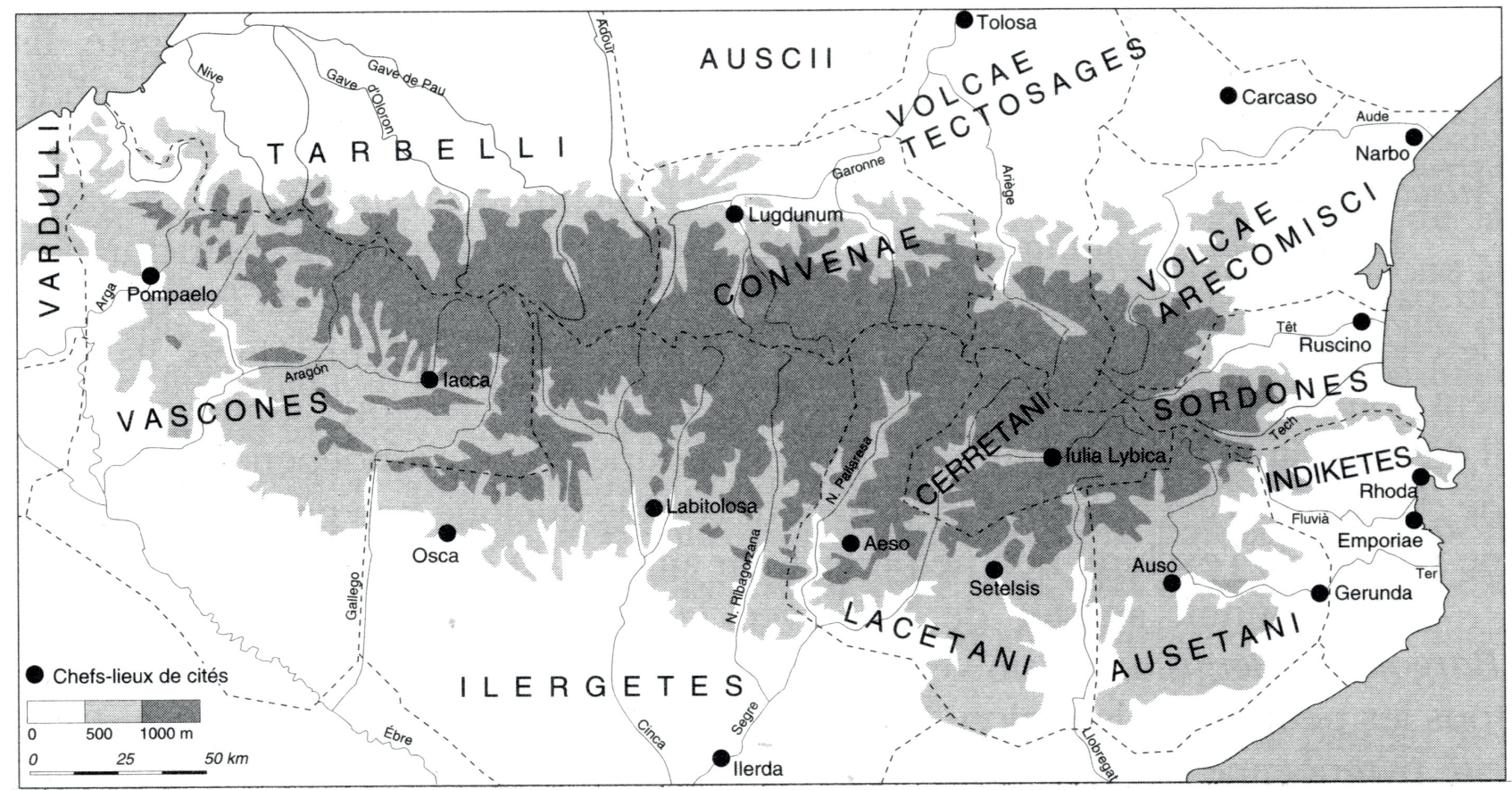

Figura 4. Aeso entre los lacetanos, según Ch. Rico (1997: 167, fig. 3).

creadas ex nihilo (Rico 1997: 176), aspecto que ahora vamos viendo que no es cierto para la primera. Es lícito también preguntarse qué tipo de interés debía existir, pues no parece haber dejado trazas materiales. Si era comercial, desde luego, lo primero que tenían que hacer ilergetes y lacetanos era conseguir salidas al Mediterráneo, zona mucho más activa en térmi- nos de circulación de productos. Tal vez se hubiera podido justificar esa "carrera" hacia el Pirineo por el control de las rutas de trashumancia desde los llanos meridionales y los altiplanos centrales a los frescos valles de montaña, pero no podemos asegurar que esa práctica hubiese existido ya en tiempos prerromanos, pues como mucho se ha propuesto para la época

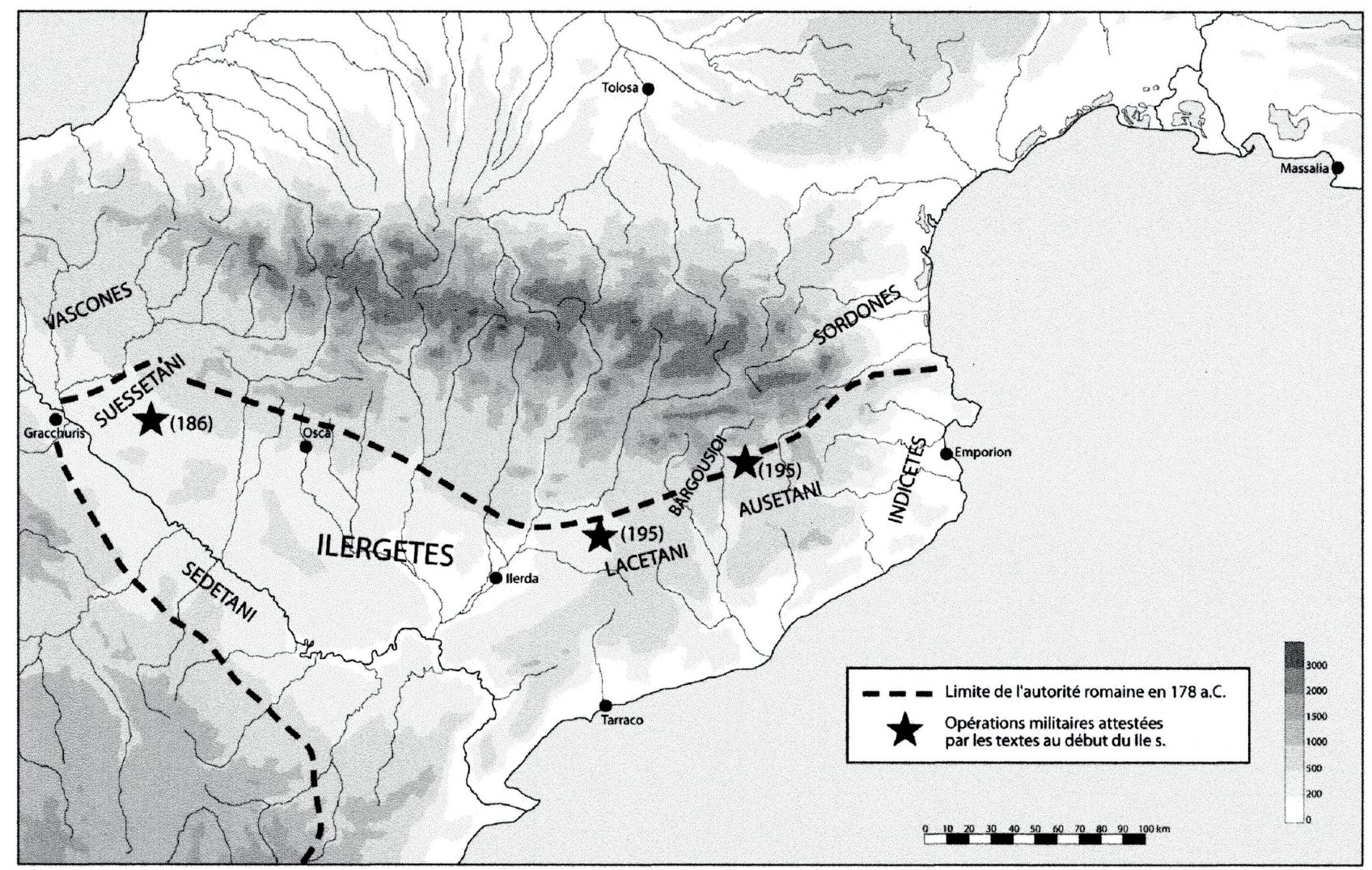

Figura 5. Propuesta del límite del control romano de Cataluña y el Valle del Ebro en 178 a. C., según Ch. Rico (2006: 211, fig. 1). 
visigoda (Sales, Salazar 2013: fig. 11). En un trabajo más reciente $\mathrm{Ch}$. Rico parece desdecirse de antiguas posiciones, situando los lacetanos solo en el centro de Cataluña, ya sometidos por los romanos en 195 a. C. (figura 5) y dejando fuera a la zona de Isona (Rico 2006: fig. 1), un sector que solo aparecería integrado en Roma con seguridad hasta después de 70 a. C., una vez finalizada la Guerra Sertoriana (Rico 2006: figura 3). Esta nueva cronología sin duda solucionaría dos cosas: el ajuste con los datos arqueológicos de la construcción de la muralla republicana de Aeso, que se sitúan a comienzos del siglo I a. C. (Payà et al. 1994a), y la cuestión de la adaptación eśo en Aeso, una hipercorrección que hemos visto no funciona en cronologías anteriores al 100 a. C.

Un aspecto sí se evidencia tanto en la propuesta de Bosch Gimpera como en la de Rico de 1997, Aeso y el Pallars no constituyen el núcleo inicial lacetano; su etnogénesis se justifica como el resultado de la expansión desde otra zona. En la revisión de la atribución de Aeso a los lacetanos es justo que nos planteemos el problema que subyace bajo la denominación de un étnico ibérico que las fuentes literarias nunca definen per se, sino a partir de sus vecinos, como bien señaló Alfred Broch (2004). Dicho autor recalca que, para los estudiosos, resulta ser el comodín que viene a ocupar aquel espacio que por exclusión resta entre el prelitoral, la montaña y el llano. En la radical formulación de Broch los lacetanos deberían ser dados de baja como etnia prerromana y ser considerados una construcción literaria, lo que, de paso, zanjaría la atribución de Aeso e, incluso, haría innecesario este escrito. Desde un punto de vista arqueológico, sin embargo, parece haber consenso en considerar una formación, llamémosle lacetana, restringida al curso central del Llobregat, la alta Segarra y algunos espacios cercanos coherentes geográficamente (Fernández 1989: 46), de la que hay dudas sobre si adscribir o no la Segarra meridional por su basculación hacia la cultura material ilergete (Pérez Conill 2010: 16). En coherencia con la cultura material Isona debería ser excluida del área Llobregat-Segarra, la designemos como lacetana o no.

\section{La alternativa: un cambio en el paradigma}

Hemos repasado hasta tres atribuciones étnicas diferentes para Aeso y ninguna resulta satisfactoria. ¿Qué hacer, entonces? Nos queda la ubicación de la ciudad romana de Aeso en la actual Isona, confirmada de antiguo por la epigrafía y la arqueología y, pese a algunas objeciones filológicas y numismáticas superables, la identificación con la eśo monetal.

Del manejo de la información literaria pueden explorarse nuevas posibilidades donde casi no hay precedentes. Cuando Federico Lara revisó la epigrafía romana de Isona llegó a considerar, en base

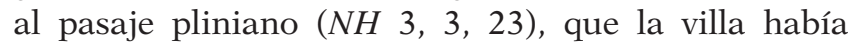
sido la sede de un grupo tribal: los aesonenses (Lara 1973: 177). Pero, lejos de explorar las posibilidades que esa sugerencia, aparentemente poco "ortodoxa", podía contener y ante la falta de otras fuentes, aceptó la atribución oficial lacetana (Lara 1973: 119, 179; 1976: 10).
Como bien sintetizó Gonzalo Cruz-Andreotti (2016: 177-178), a partir de un análisis desprejuiciado y alejado de modelos esencialistas, más detallado y preciso de la literatura geográfica — que hemos tratado de aplicar en nuestro caso al evidenciar las carencias de la atribución lacetana-, tal vez no llegaremos a conocer la identidad real de los étnicos surgidos a través de los enfoques de los diversos autores antiguos, pero sí podremos observar algunas de sus características. Lo cierto es que desde la Edad Moderna ha predominado una especie de horror vacui entre los historiadores y geógrafos. Ninguna población podía quedar sin ser atribuida a un étnico conocido o el caos se propagaría por el conjunto del sistema. Recordemos que los lacetanos, ubicados en los altiplanos y valles de la Cataluña central, nunca fueron definidos por ellos mismos sino "en relación con" sus vecinos, como bien denunció Broch (2004). Eso les confirió una especie de "elasticidad" que los hacía óptimos para cubrir huecos en el mapa.

En el caso de Aeso fue todavía más sorprendente por las formas en que han expresado el relleno de ese vacío. En la tesis lacetana, siempre acababa siendo el resultado de una expansión hacia el oeste desde áreas nucleares más allá del curso medio del Segre. Toda la trayectoria poblacional autóctona anterior, por otro lado desconocida, era irrelevante. Solo cambiaba el matiz. Para Bosch Gimpera era la necesidad defensiva contra unos supuestos peligros procedentes del oeste. Debemos preguntarnos si estaba pensando en la rivalidad con los suessetanos, recogida en las campañas catonianas (Liv. 34, 20), algo todavía presente en el discurso de F. Beltrán Lloris, que, para otorgar mayor espacio a los vascones, desplaza los suessetanos hasta Huesca, a costa de los ilergetes, y lleva los lacetanos al Alto Segre, a costa de los ceretanos, por lo que no le supone un problema que Aeso continúe siendo lacetana (Beltrán Lloris 2001: 70, 73 y mapa 2). Para Ch. Rico era la necesidad de obtener el control de paso al otro lado de los Pirineos.

Expongamos ahora dos ejemplos en otra dirección. Cuando Livio enumera los pueblos que formaron en orden de batalla ante Léntulo y Acidino, en 205 a. C., nombra a los principales, los ilergetes, a los propietarios de la zona donde tiene lugar la acción, que resultan ser los ausetanos, y a un conglomerado de aliados menores que despacha sucintamente con el descalificativo global de ignobiles Hispani populi (Liv. 29, 2, 5), bien porque no dispone de una relación detallada de los mismos, bien porque no considera necesario extenderse en detalles. Quiénes eran estos pueblos y dónde se ubicaban no lo sabemos, pero sí evidencia que la lista que habitualmente manejamos no es exhaustiva. Otro caso, en sentido contrario, se produce cuando Polibio relata el paso de Aníbal por los Pirineos y menciona unos andosini y unos airenosi (Polib. 3, 35, 1) que no vuelven a aparecer en ninguna otra fuente. Podemos deducir que si Aníbal hubiese seguido otra ruta, o si Polibio hubiese sido menos detallista, ahora no tendríamos esos nombres. Incluso podemos pensar que las propias entidades étnicas no tenían por qué ser inmutables, haberse integrado o disgregado según el momento y, con ello, haber desaparecido del registro literario. $\mathrm{O}$ 
también, aceptar con naturalidad que los autores de época romana seleccionaron determinados nombres para describir territorios quizás sin la relación con los étnicos anteriores a la conquista. Por tanto, son muchas las variables y las problemáticas que se abren, $\mathrm{y}$, en consecuencia, debemos abandonar esa urgencia en atribuir a uno u otro grupo literario casos inciertos como Aeso y su área de influencia, en especial si ello lleva a forzar las propias fuentes literarias.

Entre otras cosas, no deberíamos comenzar la casa por el tejado, que en este caso representa la información literaria. Antes de atribuir una localidad casi desconocida a una formación concreta aduciendo supuestas razones militares, comerciales o simplemente de cultura arqueológica, debería tenerse en cuenta la dinámica de una población respecto al territorio que ocupa y si esta presenta rupturas o continuidades. Esa tarea ha comenzado recientemente. Es justo acudir para ello a lo que se viene en llamar "arqueología de la etnicidad” (Fernández Götz, Ruiz Zapatero 2011). Superadas las lecturas simplistas, tales como las decoraciones cerámicas o ciertos objetos considerados representativos, que han desacreditado el discurso arqueológico tradicional tanto como el paradigma esencialista lo ha hecho con las fuentes literarias, queda por utilizar la arqueología como aportadora de características diferenciadas en la forma de vivir y de relacionarse con la naturaleza. Aquí todavía no podemos ofrecer conclusiones, solo sugerencias. Una podría ser el estudio metrológico de series de vasos comunes protohistóricos y compararlos con los resultados obtenidos en regiones vecinas, creemos que el resultado mostraría diferentes formas de concebir el entorno doméstico. Otra posibilidad sería el estudio de los rituales contenidos en los silos amortizados en El Serrat dels Espinyers, que bien podría aportar datos a tener en cuenta en el discurso.
En una dosis de realismo deberíamos limitarnos, por el momento, a considerar aquello hoy conocido, que no es otra cosa que la constatación de un grupo ibérico en el Pallars meridional que se intuye original, todavía mal perfilado, pero al que no sería ilícito denominar "esonense", aceptada la atribución numismática. Desde luego, no se trata de hacer de cada ciudad la cabecera de un grupo propio cayendo así en exagerados localismos, pues es evidente que las formaciones territoriales literarias contenían diversas ciudades, normalmente alguna ejerciendo de cabecera. La geografía del Pallars Jussà reúne condicionantes geográficas que permiten apoyar la existencia de ese "grupo esonense"; una realidad que se deberá reconstruir desde la arqueología.

Dicho grupo esonense parece disponer de al menos un centro importante en el posible oppidum antecesor de la ciudad romana de Aeso, continuadora en el nombre, que pasó de estipendiaria a recibir el derecho latino, siendo adscrita jurídicamente al convento de Tarraco junto con los lacetanos, los ceretanos y otros antiguos territorios. Potenciada por los romanos, debió ser la única ciudad del Pallars, con lo que contó con el respaldo para ampliar la influencia de su antecesora, consolidando, ahora sí, su proyección hasta el Alto Pirineo y la conexión de este con las rutas hacia el llano. Con anterioridad, la relación del grupo "esonense" prerromano con otros oppida emergentes fuera de la comarca es algo que habrá de ser determinado en el futuro.

Ignasi Garcés Estallo Departament d'Història i Arqueologia Universitat de Barcelona c/ Montalegre, 6-8 08001 Barcelona garces@ub.edu 
Amela, L. (2015). Cecas del sistema del denario ibérico del nordeste peninsular (Cataluña). Una síntesis. Asociación Numismática Española. Barcelona.

Arcos, R., Belmonte, C. (2011). Memòria del seguiment arqueològic dels nous accessos a Isona i Conques des de la C-1412b. Excavació extensiva del jaciment del Serrat dels Espinyers (Isona). Inèdit. Servei d'Arqueologia i Paleontologia. Generalitat de Catalunya.

Belmonte, C. (2015). El Serrat dels Espinyers: noves aportacions al poblament iber i romà d'Isona. Pallars Jussà (Lleida). En: Primeres Jornades d'Arqueologia $i$ Paleontologia del Pirineu i l'Aran (Coll de Nargó i la Seu d'Urgell, 2013). Generalitat de Catalunya. Barcelona: 156-171.

Belmonte, C., Garcés, I., Albizuri, S., Nadal, J., Cama, M., Batlle, S., Fernández, M., Fortuny, K., Sobrino, A., Peiró, M., Richaud, I., Román, E. (2015). La societat ibèrica al Pallars Jussà (Lleida, Catalunya): l'aportació del sitjar del Serrat dels Espinyers d'Isona. En: Actes de la VII Reunió Internacional d'Arqueologia de Calafell (març 2013). Arqueomediterrània, 14: 203-209.

Beltrán Lloris, F. (2001). Hacia un replanteamiento del mapa cultural y étnico del norte de Aragón. En: F. Villar, M. P. Fernández Álvarez (eds.). Religión, lengua y cultura prerromanas en Hispania. Universidad de Salamanca. Salamanca: 61-81.

Beltrán Lloris, F. (2012). Plinio versus Ptolomeo. Geografía y etnicidad en la Hispania del Principado. En: J. Santos Yanguas, G. Cruz Andreotti (eds.). Romanización, fronteras y etnias en la Roma Antigua: el caso Hispano. Anejos de Veleia, Revisiones de Historia Antigua VII. Vitoria: 477-498.

Beltrán Vilagrasa, P. (1953). Las cecas pirenaicas. Pirineos, 27: 17-51.

Bertran, J. (2007). Història d'Isona i la Conca Dellà. Garsineu. Tremp.

Bosch Gimpera, P. (1932). Etnologia de la Península Ibèrica. Alpha. Barcelona.

Broch, A. (2004). De l'existència dels lacetans. Pyrenae, 35-2: 7-29.

Buxeda, J., MAdrid, M. (2014). Caracterització arqueomètrica de les ceràmiques ibèriques del jaciment d'Isona, [= GARcÉs, ReYEs (coords.). Aeso, d'oppidum ibèric a municipium romà. Isona, Pallars Jussà: 92-96].

CAMPo, M. (2005). Emissió i circulació monetària al nord-est de la Hispània citerior al final de la República. En: La Moneda al final de la República: entre la tradició i la innovació. IX Curs d'Història monetària d'Hispània. Gabinet Numismàtic. Barcelona: 9-27.

Caro Baroja, J. (1952). La escritura en la España prerromana. En: R. Menéndez Pidal (dir.). Historia de España, 1-III. Espasa Calpe. Madrid: 677-812.
Carreras CANDI, F. (1908-1918). Geografia general de Catalunya, vol. I. Alberto Martín. Barcelona.

Chaves, F. (2009). Las amonedaciones hispanas en la Antigüedad. En: J. ANdreu, J. CABrero, I. RodÀ (coords.). Hispaniae. Las provincias hispanas en el mundo romano (Tudela, 2007). Institut Català d'Arqueologia Clàssica. Tarragona: 47-98.

CNH = Villaronga, L. (1994). Corpus Nvmmvm Hispaniae ante Avgvsti aetatem. J. A. Herrero. Madrid.

Collantes, E. (1997). Historia de las cecas de Hispania Antigua. Collantes. Madrid.

Cortés y LóPez, M. (1836). Diccionario geográficohistórico de la España antigua, Tarraconense, Bética y Lusitana, con la correspondencia de sus regiones, ciudades, montes, ríos, caminos, puertos e islas a las conocidas en nuestros días, vol 1. Imprenta Real. Madrid.

Cots, P. (2005). Els pobles de la prehistòria i l'antiguitat. En: C. M. Marugan, V. Rapalino (coords.). Història del Pallars. Dels orígens als nostres dies. Pagès Editors. Lleida: 13-43.

Cruz-Andreotti, G. (2009). Etnias, fronteras e identidades en la Antigüedad hispana: algunas precisiones metodológicas a partir de las fuentes escritas. Arqueología Espacial, 27: 63-77.

Cruz-Andreotti, G. (2016). Etnias e identidades antiguas. Hacia el cambio del paradigma esencialista. En: J. González Ponce, F. J. Gómez Espelosín, A. L. Chávez Reino (eds.). La letra y la carta. Descripción verbal y representación gráfica de los diseños terrestres. Estudios en honor de Pietro Janni. Universidad de Alcalá y Universidad de Sevilla. Sevilla: 167-182.

Cruz-Andreotti, G. (2017). ¿Estrabón versus Plinio? En: P. Ciprés (ed.). Plinio el Viejo y la construcción de la Hispania Citerior. Anejos de Veleia, Acta, 14. Vitoria: 87-103.

Domínguez, A. (1997). Las acuñaciones ibéricas y celtibéricas de la Hispania Citerior. En: C. Alfaro, A. Arévalo, M. Campo, F. Chaves, A. Domínguez, P. P. Ripollès. Historia monetaria de Hispania Antigua. Jesús Vico. Madrid: 116-193.

Equip PRAMA (1990). Aeso. Noves dades sobre la romanització al Pallars Jussà: actuació arqueològica a Isona 1987-1988. En: Actes del 8è Col-loqui Internacional d'Arqueologia de Puigcerdà (Puigcerdà, 1988). La romanització del Pirineu. Homenatge al prof. Miquel Tarradell. Institut d'Estudis Ceretans. Puigcerdà: 111-118.

FARIA, A. M. de (1995). Algumas notas de onomástica ibérica. Portugalia, 16: 323-330.

FARIA, A. M. de (2002). Crónica de onomástica paleohispânica (3). Revista Portuguesa de Arqueologia, 5.1: 121-146. 
FARIA, A. M. de (2007). Crónica de onomástica paleohispânica (13). Revista Portuguesa de Arqueologia, 10.2: 161-187.

FARIA, A. M. de (2008). Crónica de onomástica paleohispânica (14). Revista Portuguesa de Arqueologia, 11.1: $57-102$.

FARIA, A. M. de (2016). Crónica de onomástica paleohispânica (23). Revista Portuguesa de Arqueologia, 19: 155-174.

FERnÁNDEZ, R. (1989). Els lacetans. Interpretació a través de les fonts clàssiques, arqueològiques i numismàtiques. Estat de la qüestió. Estrat, 1: 25-51.

FernándeZ-Götz, M., Ruiz Zapatero, G. (2011). Hacia una arqueología de la etnicidad. Trabajos de Prehistoria, 68.2: 219-236.

FHA VII = BeJarano, V. (1987). Fontes Hispaniae Antiquae, vol. VII. Hispania Antigua según Pomponio Mela, Plinio el Viejo y Claudio Ptolomeo. Universidad de Barcelona. Barcelona.

FHA IX = Grosse, R. (1947). Fontes Hispaniae Antiquae, vol. IX. Las fuentes de la época visigoda y Bizantinas. Universidad de Barcelona. Barcelona.

GARCÉs, I. (1991). Assimilació, resistència i canvi a la romanització en el món ilerget: Aproximació a l'Horitzó Ibèric Tardà $i$ les seves pervivències a les comarques de plana de les províncies d'Osca i Lleida. Tesi doctoral. Universitat de Barcelona. Barcelona.

GARcÉs, I. (2005). Ilergets i lacetans occidentals. Deu anys de recerques i algunes propostes de síntesi. En: Món Ibèric als Pä̈sos Catalans, Actes del XIII Col-loqui Internacional d'Arqueologia de Puigcerdà (Puigcerdà 2003), vol. I. Institut d'Estudis Ceretans. Puigcerdà: 411-439.

GARCÉs, I. (2014a). El ressò d'una ciutat antiga al peu dels Pirineus, [= GARcés, REYEs (coords.), Aeso, d'oppidum ibèric a municipium romà. Isona, Pallars Jussà: 27-36].

GARCÉs, I. (2014b). Aeso, part de l'Imperi romà. Les inscripcions llatines, [= GARCÉs, ReYes (coords.), Aeso, d'oppidum ibèric a municipium romà. Isona, Pallars Jussà: 119-126].

GARCÉs, I., CAMA, M. (2014). La cultura material ibèrica del Serrat dels Espinyers: tradicions locals i importacions, [= GARcÉs, Reyes (coords.), Aeso, d'oppidum ibèric a municipium romà. Isona, Pallars Jussà: 68-78].

Garcés, I., Reyes, T. (coords.) (2014). Aeso, d'oppidum ibèric a municipium romà. Isona, Pallars Jussà. Societat Catalana d'Arqueologia. Barcelona.

García Alonso, J. L. (2003). La Península Ibérica en la Geografía de Claudio Ptolomeo. Universidad del País Vasco. Vitoria-Gasteiz.
García-Bellido, M. P., Blázouez, C. (2002). Diccionario de cecas y pueblos hispánicos, con una introducción a la numismática antigua de la Península Ibérica, vol. II: Catálogo de cecas y pueblos. CSIC. Madrid.

González Pérez, J. R. (1986). El poblament ibèric al nord de la ciutat de Lleida. En: Actes del bè Col.loqui Internacional d'Arqueologia de Puigcerdà, 1984. Institut d'Estudis Ceretans. Puigcerdà: 275-279.

Guadán, A. (1980). La moneda ibérica. Catálogo de Numismática ibérica e ibero-romana. Cuadernos de Numismática. Madrid.

Jordán, C. (2012-2014). Sobre los topónimos terminados en - $o$ de algunas leyendas monetales ibéricas levantinas. Faventia, 34-36: 177-188.

Junyent, E. (2003). L'albada de la civilització i els temps ilergets. En: E. Junyent, A. Pérez. Història de Lleida, vol. 1. L'antiguitat, d'Iltirta a Ilerda. Pagès Editors. Lleida: 5-184.

La CAnal, J. (1836). España sagrada, vol. XLVI. Herederos de J. Collado. Madrid.

LARA, F. (1973). Epigrafía romana de Lérida. Instituto de Estudios Ilerdenses. Lleida.

LARA, F. (1976). La religión y el culto romano en las tierras de Lérida. Instituto de Estudios Ilerdenses. Lleida.

Madoz, P. (1845). Diccionario geográfico-estadísticohistórico de España y sus posesiones de Ultramar, vol. I. Imprenta tipográfica P. Madoz y L. Sagasti. Madrid.

Mariner, S. (1972). Adaptaciones latinas de términos hispánicos. En: Homenaje a Antonio Tovar ofrecido por sus discípulos, colegas y amigos. Gredos. Madrid: 283-299.

Martín VALls, R. (1967). La circulación monetaria ibérica. Universidad de Valladolid. Valladolid.

MLH = UntermanN, J. (1975). Monumenta Linguarum Hispanicarum, I. Die Münzlegenden. L. Reichert Verlag. Wiesbaden.

Müller, K. (1883-1901). Claudii Ptolemaei Geographia. Firmint Didot. Paris.

Olives, M. (1840). Colección de Noticias ó sea Memorias para formar la historia de la antiquísima y nobilísima Ciudad de Lérida. Edición de Quintí Casals. Institut d'Estudis Ilerdencs. Lleida, 2009.

On. Cat. = Coromines, J. (1995). Onomasticon Cataloniae, vol. IV. Curial. Barcelona.

Padrós, C., Belmonte, C., Garcés, I. (2016). Indicis d'un campament tardorepublicà en el Serrat dels Espinyers (Isona, Pallars Jussà). Una nova evidència anterior a la fundació d'Aeso. Pyrenae, 47.2: 39-52.

Payà, X., Puig, F., Reyes, T. (1994a). Primeres datacions dels nivells fundacionals d'Aeso. Revista d'Arqueologia de Ponent, 4: 151-172. 
Payà, X., Puig, F., Reyes, T., Agelet, J. (1994b). Darreres intervencions al municipi romà d'Aeso (Isona, Pallars Jussà). Tribuna d'Arqueologia 1992-1993. Barcelona: 115-124.

PÉrez, A. (1994). Dos nuevas inscripciones de Isona, Pallars Jussà. Los Antonii de Aeso. Pyrenae, 25: 205-213.

Pérez, A. (1996). Las cecas catalanas y la organización territorial romano-republicana. Archivo Español de Arqueología, 69: 37-56.

Pérez, A. (1998). Tres casos de rituales fundacionales o propiciatorios en construcciones domésticas del Alto Imperio romano ¿Latinidad o indigenismo? Arys: Antigüedad: religiones y sociedades, 1: 195-206.

Pérez, A. (1999). El elemento forastero en el municipio de Aeso (Isona, Lleida). En: Homenaje al Profesor Montenegro. Estudios de Historia Antigua. Universidad de Valladolid. Valladolid: 361-374.

Pérez, A. (2002). El elemento militar de origen celtíbero y la aristocracia municipal de Aeso (Isona, Lleida) a través de la epigrafía. Arqueología militar romana en Hispania, Gladius Anejos, 5: 519-527.

Pérez, A. (2003). Lleida romana i antiga tardana. En: E. Junyent, A. Pérez. Història de Lleida, vol. 1: L'antiguitat, d'Iltirta a Ilerda. Pagès Editors. Lleida: 185-397.

Pérez Conill, J. (2010). La Segarra entre els lacetans i els ilergetes. Una aproximació a la cultura ibèrica en aquesta comarca. Miscel-lània Cerverina, 20: 11-22.

Piera, M., Pancorbo, A., Garcés, I., Gallart, J. (2013). Els assentaments de les edats del bronze, ibèrica i romana dels Llirians del Mas i Les Torres (Salàs de Pallars, Pallars Jussà). Revista d'Arqueologia de Ponent, 23: $163-200$.

Pina Polo, F., Alfayé Villa, S. (2002). Propuesta de ubicación de los volcianos en el área prepirenaica. Palaeohispanica, 2: 201-211.

PitA, R. (1952). Gentilidades y ciudades del pueblo ilergete. Argensola, 12: 293-319.

Pita, R. (1963). Prospección arqueológica en Isona (Lérida). Ampurias, XXV: 219-224.

Pita, R. (1967). La Historia Antigua y arqueología del Pallars. Institut d'Estudis Ilerdencs. Lleida.

PitA, R. (1975). Lérida Ilergete, vol. I. Dilagro. Lleida.

Pons, J. (1982). Conflictes i dualitat socioeconòmica a la Catalunya pirenaica durant l'Alt Imperi. Fonaments, 3: 11-44.

Rico, Ch. (1997). Pyrénées romaines. Essai sur un pays de frontière (III siècle av. J.-C. - IVe siècle ap. J.-C.). Bibliothèque de la Casa de Velázquez, 14. Madrid.

Rico, Ch. (2006). L'“invention” romaine des Pyrénées, ou les étapes de la formation d'une frontière. En:
G. Cruz Andreotti, P. Le Roux, P. Moret (eds.). La invención de una geografía de la Península Ibérica, I. La época republicana, Actas del Coloquio Internacional celebrado en la Casa de Velázquez (Madrid, 2005), vol. III. Casa de Velázquez. Málaga-Madrid: 199-215.

RiPOllès, P. P. (1996). Fiscalitat i política monetària. En: B. DE Riguer (dir.). Història, política, societat $i$ cultura dels Pä̈sos Catalans. Els temps prehistòrics $i$ antics fins al segle V, vol. I. Enciclopèdia Catalana. Barcelona: 312-315.

Rodríguez, F. (1992). Concilium Toletanum VI, en G. Martínez, F. Rodríguez. La colección canónica Hispana, V. CSIC. Madrid: 293-336.

Rodríguez Morales, J. (2001). Paemeiobrigenses y ailobrigiaecinos en el bronce de Bembibre. En: L. Grau, J. L. Hoyas (eds.). El bronce de Bembibre: un edicto del emperador Augusto del año 15 a.C. Museo de León. Junta de Castilla y León, Consejería de Educación y Cultura. León: 111-122.

Roig i Rey, R. (1868). Sobre la villa de Isona. Memoria leída en la Academia de Buenas Letras de Barcelona, el dia 15 de Enero de 1839 por el socio D. Ramon Roig y Rey. Memorias de la Real Academia de Buenas Letras de Barcelona, II: 221-240.

Rovira i Virgili, A. (1922). Història de Catalunya, vol. 1. Edición facsímil. Bilbao, 1972.

Sales, J., Salazar, N. (2013). The pre-Pyrenees of Lleida in Late Antiquity: christianisation process of a landscape in the Tarraconenses. Revista d'Arqueologia de Ponent, 23: 27-44.

SÁnchez i Vilanova, L. (1996). El Pallars. Visió històrica, 2 vols. PPU. Barcelona.

Sanfeliu, G. (1977). Els imprecisos límits de la Segarra. Grup de Recerques de les Terres de Ponent. Tàrrega.

SAnfeliu, G. (2009). Origen històric de les comarques catalanes. Grup de Recerques de les Terres de Ponent. Verdú.

Siles, J. (1985). Léxico de inscripciones ibéricas. Ministerio de Cultura. Madrid.

TIR = CEPAs, A., Guitart, J., FAtÁs, G. (1997). Tabula Imperii Romani. Hoja K/J-31, Pyrénées OrientalesBaleares. Instituto Geográfico Nacional. Madrid.

Tovar, A. (1989). Iberische Landeskunde, vol. 3. Tarraconensis. Valentin Koernen. Baden Baden.

Velasco, A. (2011). Jaume Pasqual, antiquari $i$ col-leccionista a la Catalunya de la Il-lustració. Universitat de Lleida. Lleida.

Velaza, J. (2011). El elemento $-o$ en la formación de topónimos del área lingüística ibérica. En: M. J. García Blanco, T. Amado, M. J. Martín, A. Pereiro, M.

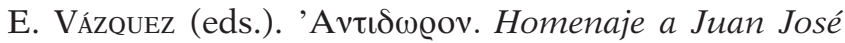


Moralejo. Universidad de Santiago de Compostela. Santiago de Compostela: 567-572.

VillaR, F. (2000). Indoeuropeos y no indoeuropeos en la Hispania Prerromana: las poblaciones y las lenguas prerromanas de Andalucía, Cataluña y Aragón según la información que nos proporciona la toponimia. Universidad de Salamanca. Salamanca.
VILLAR, F. (2001). Indoeuropeos y no Indoeuropeos en la Península Ibérica. En: F. VILlar, M. P. Fernández Álvarez (eds.). Religión, lengua y cultura prerromanas en Hispania. Universidad de Salamanca. Salamanca: 257-283.

Villar, F., Prósper, B. M., Jordán, C., Fernández, M. P. (2012). Lenguas, genes y culturas en la Prehistoria de la Europa y Asia suroccidental. Ediciones de la Universidad de Salamanca. Salamanca. 